\title{
Foreign Direct Investment Opportunity for Modified Cassava Starch in Indonesia
}

\author{
Respati Wulandari ${ }^{1 *}$, Gita Amanda ${ }^{2}$, Reynaldo Damara Salim ${ }^{3}$ \\ ${ }^{1,2,3}$ BINUS Business School, International Business Management, \\ Bina Nusantara University, \\ Jakarta 11480, Indonesia \\ respati.wulandari@binus.edu; gitamanda@binus.ac.id; damarareynaldo@binus.ac.id \\ *Correspondence: respati.wulandari@binus.edu
}

\begin{abstract}
Modified cassava starch is widely used in a range of applications such as food and beverage, papermaking, textiles, chemicals, constructions, adhesives, and pharmaceuticals. Hence, there is a massive demand for modified cassava starch in Indonesia. Nowadays, in the agricultural sector, our production capacity is only 1\% of the total demand and this means that there are not many modified starch plantations in Indonesia. The aim of this research is to identify the external and internal factors that influence the foreign direct investment potential of modified cassava starch in Indonesia.
\end{abstract}

Keywords: Modified Cassava Starch; Foreign Direct Investment.

\section{INTRODUCTION}

Current President Joko Widodo continues to thrive endlessly to improve Indonesia's economy, said the coordinator of the Ministry of Economic Affairs (ekon.go.id, 2015). Two years later, after the start of his presidential term, the economy improved to a much better state (Deny, 2017). We can see below since JokoWidodo's presidential election, the government has started to maximize capital investment.

\section{FDI Based on Capital Investment Activity in Indonesia}

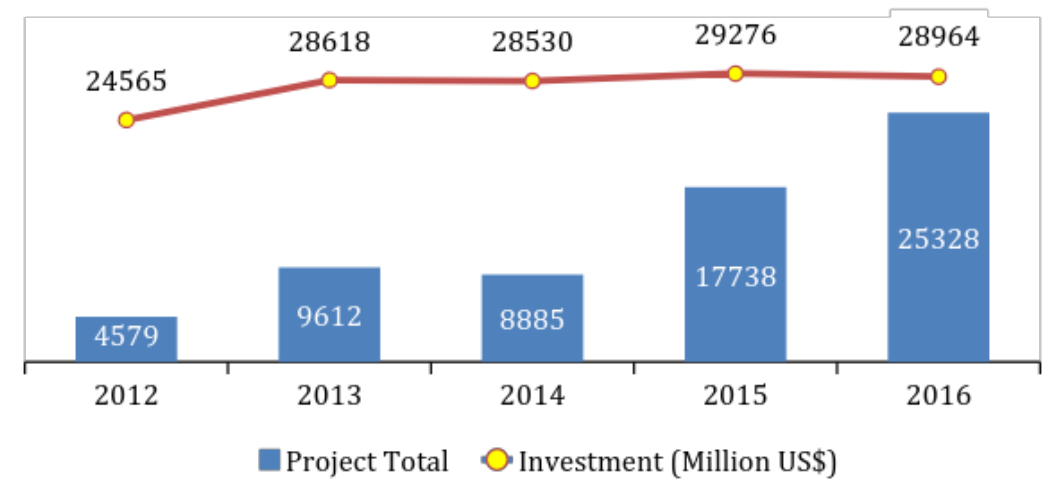

Figure 1. FDI Based on Capital Investment Activity in Indonesia (bkpm.go.id, 2017) 


\section{FDI Capital Investment Activity on Agriculture in Indonesia}

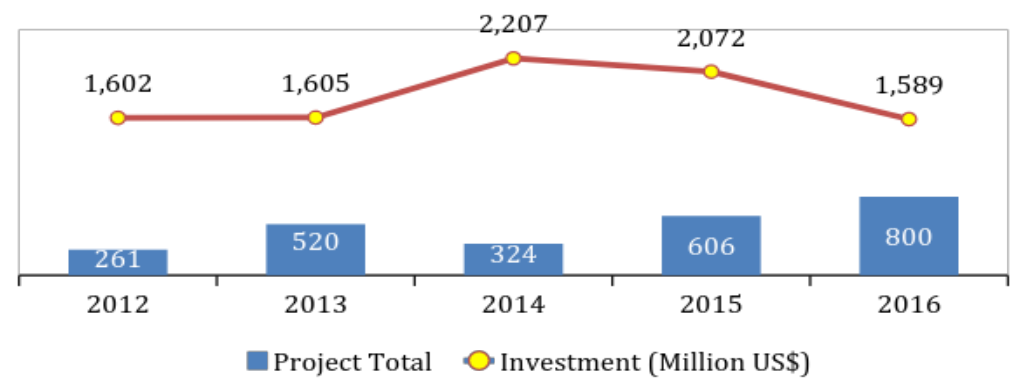

Figure 2. FDI Based on Capital Investment Activity on Agriculture in Indonesia (bkpm.go.id, 2017)

When we focus on the agricultural sector in Indonesia, there is a growth of projects, despite the decrease in investments over the past two years. Nowadays, from the agricultural sector, our production capacity is only $1 \%$ of the total demand and this means that there are not many modified starch plantations in Indonesia (Rahman, 2015). Meanwhile, foreign direct investment for modified starch is still full of opportunities and potentials. It would be interesting to develop something that Indonesia already has in abundance, namely cassava.

First, modified cassava starch is widely used in a range of applications such as food and beverage, papermaking, textiles, chemicals, constructions, adhesives, and pharmaceuticals. Asia being the center of production and consumption trends in the global modified starch market. Cassava starch in Asia is estimated to be the main driver in the future, in fact, Asia-Pacific accounted for the largest share in terms of value and volume (Claire, 2017). Growing consumer awareness of health and wellness has led to a shift towards high nutritional value foods. In addition, the increasing demand for natural sweeteners in food and drink is likely to stimulate growth in the near future. It is even expected to reach USD 15.36 billion by 2024 (grandviewresearch.com, 2016).

Second, to anticipate the fall in cassava prices during the harvest season in Indonesia, farmers in Lampung were constantly reminded not to sell raw cassava, or in this case to produce modified starch instead ( Budiman, 2016). As a result, new factories will need to be built, which will open up a new market and meet customer demand. Besides earning income and profit, modified cassava flour can create new jobs for unemployed people in Indonesia.

A main factor explains why imports continue to increase in Indonesia. Manufacturing companies believe that importing will be much more profitable than their own production, as the price of products in the country is no longer competitive. This condition is aggravated by rising production costs such as electricity tariffs, staff salaries, tolls and infrastructure (Wanandi, 2013). In short, producing and maintaining their own factory would be very unprofitable.

Table 1. Import Statistic November 2016 - April 2017 (Indonesia Custom Excises, 2017)

\begin{tabular}{|c|c|c|c|c|c|c|c|c|c|c|}
\hline & & \multicolumn{2}{|c|}{2016} & \multirow{2}{*}{2016} & \multicolumn{4}{|c|}{2017} & \multirow{2}{*}{2017} & \multirow{2}{*}{ Last $12 \mathrm{Mo}$} \\
\hline & & Nov & Dec & & Jan & Feb & Mar & Apr & & \\
\hline \multirow[t]{2}{*}{ INDAH KIAT } & Vol (ton) & 2,890 & 1,819 & 4,709 & 2,247 & 1,400 & 2,210 & 1,213 & 7,069 & 11,778 \\
\hline & Price (\$/ton) & 573 & 550 & 564 & 563 & 583 & 555 & 585 & 568 & 566.60 \\
\hline \multicolumn{2}{|c|}{ PT. PABRIK KERTAS TJIWI KIMIA TBKVol (ton) } & 1,198 & 789 & 1,987 & 1,913 & 977 & 646 & 821 & 4,357 & 6,344 \\
\hline & Price $(\$ /$ ton $)$ & 619 & 569 & 599 & 586 & 604 & 583 & 587 & 590 & 592.77 \\
\hline \multirow[t]{2}{*}{ INGREDION } & Vol (ton) & 677 & 614 & 1,291 & 654 & 721 & 836 & 824 & 3,034 & 4,326 \\
\hline & Price (\$/ton) & 1,163 & 949 & 1,061 & 1,072 & 982 & 963 & 1,183 & 1,051 & $1,054.00$ \\
\hline \multirow[t]{2}{*}{ PT. SURYA PAMENANG } & Vol (ton) & 624 & 516 & 1,140 & 221 & 360 & 936 & 144 & 1,661 & 2,801 \\
\hline & Price (\$/ton) & 589 & 569 & 580 & 590 & 690 & 588 & 847 & 633 & 611.21 \\
\hline \multirow{2}{*}{ PT. CONNELL BERSAUDARA } & Vol (ton) & 171 & 364 & 535 & 397 & 501 & 465 & 315 & 1,679 & 2,214 \\
\hline & Price (\$/ton) & 819 & 738 & 764 & 723 & 805 & 748 & 811 & 771 & 769.39 \\
\hline Total Vol (ton) & & 5,560 & 4,102 & 9,662 & 5,432 & 3,959 & 5,093 & 3,317 & 17,801 & 27,463 \\
\hline Total Price $(\$ /$ ton $)$ & & 664 & 633 & 651 & 645 & 699 & 649 & 767 & 681 & 670.31 \\
\hline
\end{tabular}

From the import statistics data of April 2017, you can see that the major industries have a high import demand. Foreign direct investment in itself has been one of the most beneficial ways to maximize the level of the host country in many areas, including improving a competitive business environment, contributing to 
trade integration international development and improving business development (Kastrati, 2013). Meanwhile, the positive effects of engaging FDI, which are dynamic and constantly evolving, are often still overlooked by governments (Narula and Pineli, 2016).

Regarding agricultural products, when a country has a low FDI, this indicates a low quantity sufficient for the agricultural sector. When FDI in the agricultural sector is low, it can be concluded that the resources and its potential have not been exploited. Hence, by maximizing its potential benefits and taking the right measures to attract and increase FDI in this sector (Jovovic et al, 2014). In addition, the benefits of agricultural investment are not only for the country's macroeconomics, but also to help farmers in agricultural contracts which included provision of seeds, price risk, access to credit and buying companies (Adhana, 2016).

As Indonesia is a developing country, it relies heavily on FDI to foster the growth and development of the country. Indonesia's contribution to FDI is relatively small compared to other ASEAN countries. FDI alone will help increase productivity and improve access to the global market for Indonesia, as competition among ASEAN countries continues to intensify more than ever (Danya and Ramachandran, 2014 ). Therefore, improving market access and therefore the income of local small farmers depends quite largely on the country's investment (Tambunan, 2014).

Based on the above barriers, knowledge of FDI and its benefits has not been maximized especially in the agricultural sector, more particularly modified cassava starch. In order to try to foster the modified cassava starch market opportunities in Indonesia through the investment of MNEs, it is essential to have in-depth knowledge from the interviews with its actors and government organizations on the obstacles to FDI. in Indonesia. We apply the relevant theory in order to make the most applicable recommendations so that foreign investors can profit from the modified starch demands on Indonesia.

\section{Foreign direct investment in Indonesia}

First, as the end of President JokoWidodo's term approaches in less than two years, the pressure to revive a failing economy is increasing. Compared to the other two giants, China and India, there is a significant difference in growth rate with Indonesia whose investment rates remain stagnant (Gopalan et al, 2016). However, the growth of FDI in Indonesia appears even higher than the global trend. In the opinion of Indonesian investors, the massive influx of FDI will certainly continue. Indonesia was ranked the fourth most popular potential host country for FDI in 2012 (Sjoholm, 2016). Second, since 1997 on the global economic level, Indonesia has been one of the countries that depends on FDI inflows to promote sustainable economic development (Fitriandi et al, 2016). Indonesia's FDI inflows to the world have grown steadily since the early 2000s. Between 2002 and 2013, total FDI inflows into Indonesia averaged around US \$ 8 billion. . Its peak came in 2005, with a share of 3\% of Indonesia's GDP. Indonesia's global FDI inflows increased from around US \$ 19 billion in 2013 to US \$ 23 billion in 2014 and rank 14th globally (Gopalan et al, 2016).

\section{Cassava in Indonesia}

Indonesia's current economic structure focuses primarily on agriculture and industries that extract and harvest natural resources (Rahmadyanti and Dwijanto, 2016). Cassava itself is a plant with great potential to be used as an industrial base. Its function ranges from corn, rice to starches and it continues to evolve into a multi-billion dollar company worldwide for various industrial applications. Some countries have developed starch for multipurpose applications, particularly cassava starch. (Tonukari et al, 2015). Cassava production in Indonesia, especially in Java only, $65 \%$ was used for human consumption. Particularly in areas where cassava has been planted and consumed for a long time, the government has fundamentally recognized the important role of cassava in promoting national food security (Saediman et al, 2016). The remaining 35\% of cassava production in Indonesia is used as a raw material for the starch industry, fuel and animal feed (Widiastuti et al, 2015).

According to Newby (2017), there are market prospects for cassava applications in Indonesia, such as gaplek (fresh roots) for direct consumption, and ethanol, maize, sorghum, wheat oil and animal feed. In addition, there are also challenges for cassava in Indonesia:

- Cassava growers face a reduction in cassava root prices and reduced household income.

- Reduction in the competitiveness of local cassava caused by a substitute product and an alternative market.

- Lack of policies promoting innovation and competitiveness of local cassava.

- No improvement in productivity and reduction in costs, although these are the main viable actions for the current state. 


\section{Pestle analysis}

Nowadays, some organizations use tools that help in decision making process, strategic planning and action planning. The PESTLE analysis tool helps organizations or businesses identify internal and external factors for a successful project (UNICEF, 2015). PESTLE can also be used to assess the potential attractiveness of the market (Nganga and Maruyama, 2015). The main aim of PESTLE analysis is to examine the position and condition of a particular company or sector, the second objective is to examine the feasibility of a management solution in the business environment ( Talib, 2014). The PESTLE analysis tool includes all relevant political, economic, sociological, technological, legal and environmental factors (Anton, 2015).

\section{- Politics}

Transition in a political climate that includes transition of government, regulation and legislation (Gupta, 2013). These circumstances of political intervention call for activities in the economy (Ho, 2014).

\section{- Economic}

The performance of the economy, such as the rate of inflation, has a direct impact on purchasing power, supply power and also the attractiveness of a country's direct foreign investment (Rastogi and Trivedi, 2016 ), the number of unemployed can also affect the economic performance of a country (Koumparoulis, 2013).

\section{- Sociological}

Social factors are often the most difficult to predict, as some factors will be seen as personal such as attitudes, values and beliefs (CMI, 2013). Non-personal factors such as lifestyle trends, demographics and shopping habits (Vieira, 2015).

\section{- Technological}

The development of the technology is driven by an increased demand for alternative energy integrated with the needs of the market which must be met by the technologies (Harrell, 2016). These factors indirectly favor government supports that encourage innovation initiatives and technological change (Dockaliva and Kashi, 2014).

\section{- Legal}

Factor related to the legal environment in which companies operate, such as labor law, competition law and consumer rights (Yuksel, 2012). The legal factor is really important to take into account, especially if there are changes in the coverage and depth of the law (Francisca \& Lantu, 2014).

\section{- Environment}

External forces in the form of ecological problems such as climate change and weather conditions will affect the costs of business and other finances (Litavniece and Znotina, 2015).

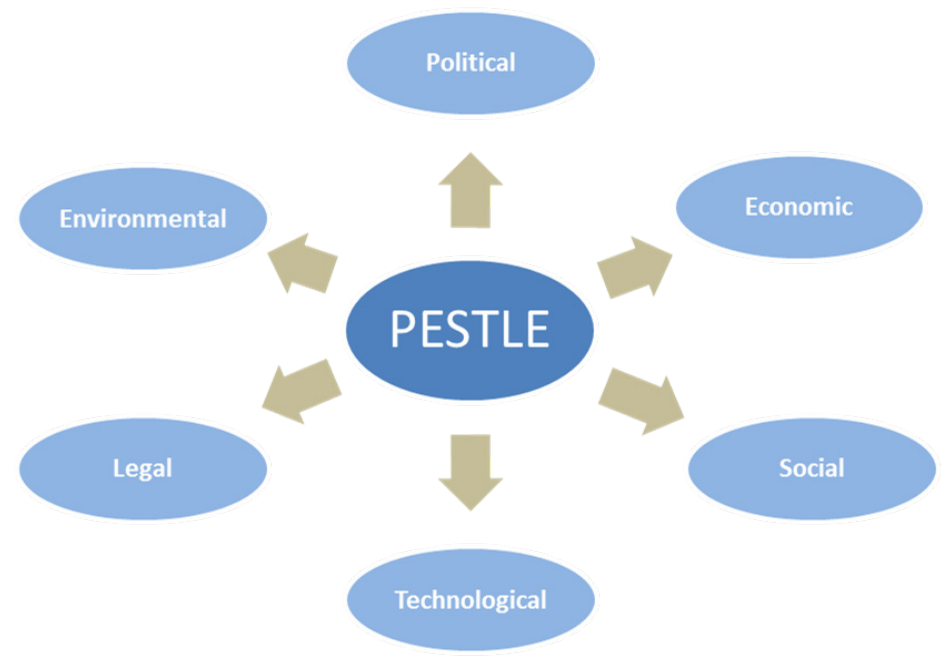

Figure 2. PESTLE (David, 2016) 


\section{Porter's five forces analysis}

Competition between industries is affected by undeniable forces that go into shaping the structure of the market. Market structure often affects the attractiveness of an industry and it is also one of the factors that influence the behavior of market players (Dalken, 2014). Attractiveness means the profitability of industry offerings, its profitability must be thought of whether to enter the market or to avoid. The stronger the five forces can lead to less profit, therefore, the less attractive can be more powerful to enter the market (Johnson, 2014)

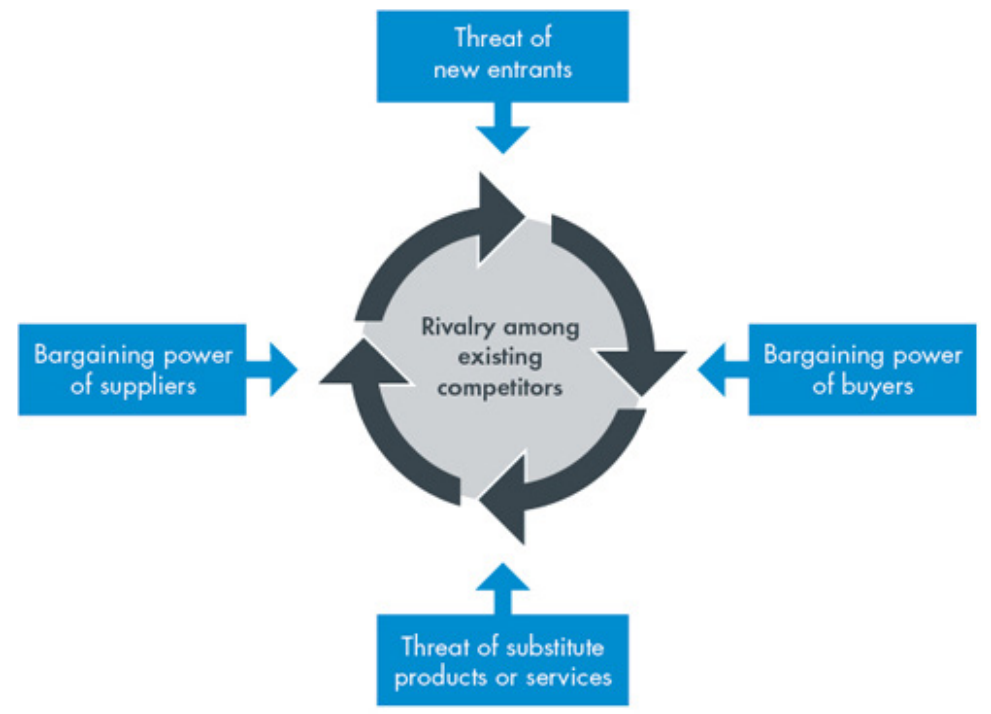

Figure 2. Porter's Five Forces Analysis (Johnson, 2014)

\section{- Rivalry between existing competitors}

The competitor is the first thing to consider in a competitive environment, rivalry often occurs between competitors, especially when they feel a certain sense of pressure or act on an opportunity to win their market segment (Indiatsy et al, 2014 ).

\section{- The threat of new participants}

New entrants to an industry create new capabilities that will put a lot of pressure on prices, costs and investment rates to be competitive (Eskandari et al, 2015). The threat of new entrants in the industry depends on the barriers to entry into the market, a high barrier leads to a low rate of new entrants and vice versa (Mel et al, 2016).

\section{- Bargaining power of suppliers}

The supplier provides different types of products and services, high bargaining power determined by high prices or limitation of products and services (Deri, 2015). This usually happens when a product or service has many buyers or low demand (Ozer and Saldamli, 2015).

\section{- The bargaining power of buyers}

The buyer may threaten the industry by expecting better quality or services that reduce profits, the buyer's bargaining power depends on the market situation and the importance of the product or service (Indiatsy, 2014).

\section{- Threat of substitute}

A replacement product is one that replaces the current product with the same value or potential value that satisfies the needs of the customers, but it appears to be different (Njambi et al, 2016), the potential replacement product can reduce costs, improve quality performance and better value (Cheng, 2013). 


\section{RESEARCH METHOD}

During this research, researchers use qualitative methods to analyze qualitative data such as interview notes, focus group transcripts, video recording transcripts, new articles, etc. can be obtained through a wide variety of primary and / or secondary resources such as individuals, corporate records, government publications and reports (Sekaran \& Bougie, 2014).

The research was carried out for 3 months and we interviewed 5 experts ( 3 end users, 1 local producer and 1 government organization). Each interview with the expert lasted 30 to 45 minutes and was recorded.

Table 2. Respondents Profile

\begin{tabular}{ccccc}
\hline Nama & Experts & Role & Working Years & Category \\
\hline Nana Suryana & $\begin{array}{c}\text { PT Indah Kiat Pulp \& } \\
\text { Paper Tbk }\end{array}$ & $\begin{array}{c}\text { Laboratory quality } \\
\text { control and Research \& } \\
\text { Development supervisor }\end{array}$ & 26 years & $\begin{array}{c}\text { End user } \\
\text { (Pulp \& Paper) }\end{array}$ \\
\hline DodyChristianto & $\begin{array}{c}\text { PT Fajar Surya } \\
\text { WisesaTbk }\end{array}$ & Senior Purchaser & 10 years & $\begin{array}{c}\text { End user } \\
\text { (Pulp \& Paper) }\end{array}$ \\
\hline Yuliana & $\begin{array}{c}\text { PT Bangun Cipta } \\
\text { Mandiri }\end{array}$ & $\begin{array}{c}\text { Marketing and Business } \\
\text { Development }\end{array}$ & 4 years & Manufacturer \\
\hline SeptiriaChristianti & $\begin{array}{c}\text { Indonesia Investment } \\
\text { Coordinating Board } \\
\text { (BKPM) }\end{array}$ & Kasubdit Agribusiness & 10 years & $\begin{array}{c}\text { Government } \\
\text { Organization }\end{array}$ \\
\hline Rika Kartika & $\begin{array}{c}\text { PT Pulcra Chemicals } \\
\text { Indonesia }\end{array}$ & Purchasing and Planner & 3 years & $\begin{array}{c}\text { End user } \\
\text { (Textile \& Leather) }\end{array}$ \\
\hline
\end{tabular}

\section{RESULTS AND DISCUSSION}

We present the results of our research and our analysis of the factors that influence the potentiality of foreign direct investment in modified starch in Indonesia. The analytical tool we applied to identify the internal factors that create the attractiveness of the industry is Porter's Five Forces Analysis. In order to know the external aspects in the form of barriers or the current conditions of Indonesia that force foreign direct investment, we used the PESTLE analysis tool to identify these political, economic, social, technological, legal and other barriers. environmental. Throughout this chapter, we also provide our analysis based on our interview with several expert professionals from the modified starch industry and an expert from Indonesia Investment Coordinating Board. The implications of the research are divided into theoretical and managerial implications, the results are created by the integration between the study of the literature and the interview data collected.

\section{Modified cassava starch applications}

In recent years, modified cassava starch has been produced for many industrial applications using a variety of methods. Untransformed native starches are structurally too weak and functionally too limited for various applications. Thus, according to Singh, Singh and Nath (2017), industries that use modified cassava starch as a raw material are:

- Pharmaceutical / medical industry as excipients, volumizers, etc.

- Food industry as a stabilizer, preservative, aroma encapsulation, mouth feel, etc.

- The paper industry as a bonding agent, filler and adhesive.

- Textile industry as finishing, weaving and printing of fabrics.

- Plastic industry as filler and densifier.

- The oil industry as a drilling agent. 


\section{Porter's five forces analysis}

The aim of Porter's Five Forces is to determine the attractiveness of an industry. It is a combination of 5 forces: rivalry among existing competitors, threat of new entrants, threat of substitute products, bargaining power of suppliers, and bargaining power of buyers. These forces will help determine the level of competition in that industry. The stronger competitive forces in the industry the less profitable it is, and vice versa. As a result, based on our interview we conclude five porter's analysis below:

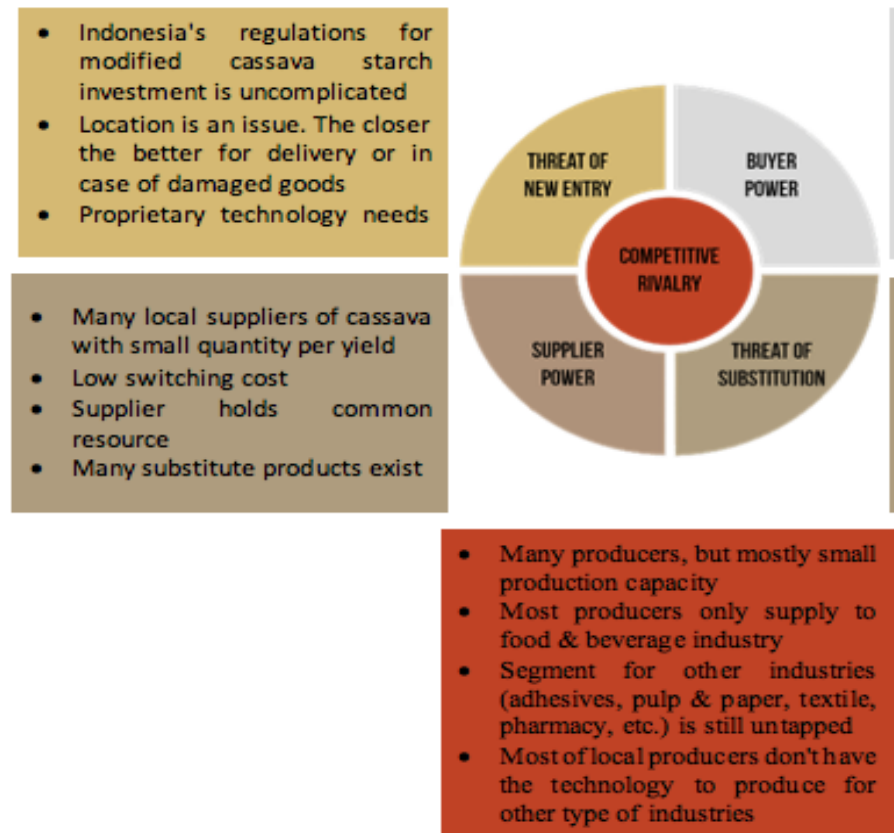

- Huge number of demands of modified starch, especially in paper and textile industry

- Switching cost of product is low

- Low price sensitiveness due to high demand on product quality

- Large usage quantity per

- Substitute product's (starch made from corn, wheat, potato) price only differs slightly than modified starch price

Tendency to substitute to other products is low

Figure 3. Modified Cassava Starch Industry’s Porter Analysis (Researchers, 2018)

\section{- Rivalry among existing competitors}

Modified cassava starch can be considered as a new product in the market, especially when used as a raw material for industrial production. Even for the producers of modified cassava starch itself, there are only several producers capable of supplying more than 100 tons / month. According to Yuliana of PT BangunCipta Mandiri (2017), the others are mostly small and medium enterprises (SMEs) which barely reach 30 tonnes / month. Typically, producers only supply the food and beverage industry. A very unfortunate situation, when the application of modified cassava starch is very diverse and the other segments are still untapped.

Cassava starch buyers mentioned that they were struggling to find supplies as local suppliers could not meet their demand. One of the reasons why there is no competitive rivalry among suppliers could be that the technology at the plant is lacking. The reason is simply because they don't know that modified cassava starch can be processed into so many different products, hence the machines are not able to produce modified cassava starch for other types. industries, said Rika Kartika of PT Pulcra Chemicals (2017). . While Thailand has developed its technologies by operating mechanized processes in its factory (Win, 2017).

\section{- Threat of new entrants}

For Indonesia, the threats could only be based on the fact that government regulations are straightforward regarding investments of any kind. From our interview with several types of different sources, official national organizations have notably stated that investment in Indonesia is facilitated by the current President JokoWidodo. Therefore, foreign direct investment by multinational enterprises (MNEs) is a popular idea. According to SeptiriaChristiani of the Investment Coordination Board in Indonesia (2017), this could lead to an increase in the number of suppliers of modified cassava starch throughout the year, as the demand keeps increasing every year.

In addition, location is a problem for buyers. For buyers, all they care about is meeting their demand and getting production started by getting the raw material delivered on time. The closer the better in terms of delivery and in the event of returns due to damaged goods. As long as the quality meets their specifications, all suppliers can do the job for them, mostly local suppliers. In addition, the quality of the modified cassava starch is also a consideration (DonyChristianto de PT Fajar Surya Wisesa, 2017). 


\section{- Threat of substitute products}

In terms of substitute products, according to Nana Suryana of PT Indah Kiat (2017), the main threat is the slight price difference between modified cassava starch and substitute starch products. Modified cassava starch can be easily replaced with another modified starch made from different raw materials for several industries. Even though the modified starch is designed to customized specifications for different applications, it can use any raw material (corn, wheat, potato) during the production process.

However, the tendency to substitute for another product is low. In order to change the raw material (in this case modified starch), the company would have to check and do some research on their lab to find out if it is working well or not. This step is long and one that companies would choose to avoid. Therefore, it is no wonder that the demand for modified cassava starch is not affected, said Rika Kartika of PT Pulcra Chemicals.

\section{- Bargaining power of suppliers}

Cassava is abundant in Indonesia, hence many suppliers of cassava in large quantities. The demand of a single customer can reach 1,000 tons / month. The local supplier can easily meet the demand as he has no difficulty in finding the resource, even if it is seasonal. Apparently Thailand is no different. According to Win (2017), demand for cassava starch is increasing dramatically in the market in 2017, that is why Thailand has developed the modern starch manufacturing process to produce 15-16 million tons of starch from cassava every year.

If for some reason the cassava price drops in Indonesia, suppliers will continue to source cassava from local farmers, resulting in no replacement costs. Unfortunately, in the process of making modified starch, cassava can be replaced by other raw materials such as potato, maize and wheat (Yuliana from PT BangunCipta Mandiri, 2017).

\section{- The bargaining power of buyers}

From this research, we analyze that there is a massive demand for modified cassava starch in Indonesia. According to Rika Kartika of PT Pulcra Chemicals, requests are coming from a variety of industries ranging from food and beverage to pulp and paper, custom specifications to ordinary modified cassava starch.

In addition, the replacement cost of the modified cassava starch buyer is relatively low and has virtually no price sensitivity, because a slight price difference between the modified cassava starch from Thailand and the Indonesia is not a big deal for buyers as they usually order in large quantities. This translates into strong buyer's bargaining power, said DodyChristianto of PT Fajar Surya Wisesa (2017).

\section{Pestle analysis}

The purpose of PESTLE analysis is to identify external and internal influence factors. Therefore, there are six categories factors: political, economic, social, technology, legal and environment (Srdjevic, Bajcetic, \&Srdjevic, 2012).

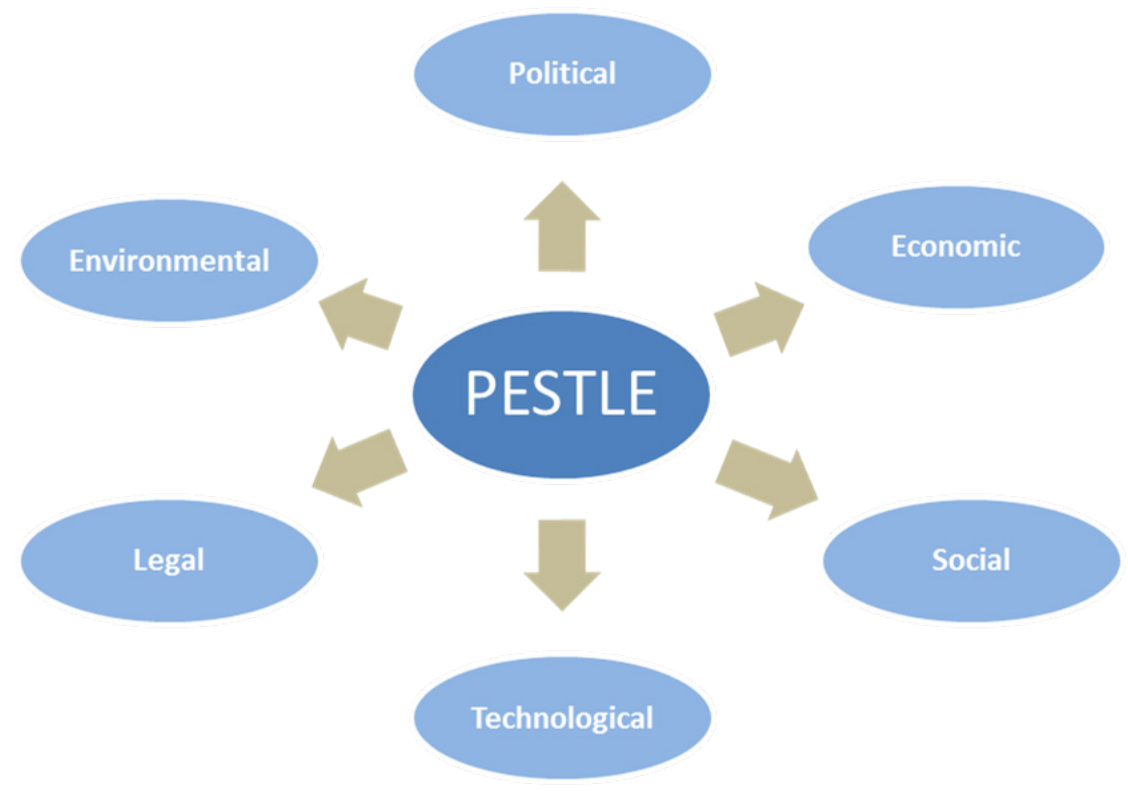

Figure 4. PESTLE (David, 2016) 


\section{- Political}

According to Septiria Christiani of Indonesia Investment Coordinating Board (2017), political or policy changes have no influence on agricultural investment itself because the investment climate in Indonesia is increasing every year, but something else that has appeared and one should be aware and concerned about political changes, could be the fluctuation of the exchange rate which will affect international trade, especially on the import of cassava or perhaps the import of modified starch. Another concern that most affects foreign investment is regulation, especially in the regulation of agricultural investments made by former president Susilo Bambang Yudhoyono which has restricted the full ownership of foreign companies. This regulation makes investments in the agricultural sector less attractive. Since President Joko Widodo halted regulation and made it easier to do business in Indonesia, foreign companies should seize and take advantage of this opportunity.

\section{- Economic}

Indonesia is in the top 5 ASEAN economies to grow beyond 5\% year on year, this means huge economic growth in Indonesia is attracting foreign investors to do business in Indonesia, but it has fluctuated for agricultural investments since 2014. Indonesia is always seeking a balance between economic growth and sustainable environment. Consumption in relation to products and services has increased over the years, but the other

The problem behind the huge growth is the green problem that causes so many land acquisitions from farm to residence or to urban city (Septiria Christiani of the Indonesia Investment Coordination Board, 2017).

\section{- Social}

Social issues are now the main factor that the government should pay more attention to in Indonesia. Especially in Java, the majority of people are well educated and open to change, it helps companies to run their factory without any social problem if they invest in Java. In eastern Indonesia, especially Papua and eastern Nusa Tenggara, when a foreign company decides to invest and operate a factory, it must train human resources to help them operate the plant. daily production. However, the villagers usually decide to refuse foreigners to work on their land and insist on forcibly closing the factory. This social issue made a foreign company think twice, said Septiria Christiani of the Indonesia Investment Coordination Board (2017). From a different perspective, when it comes to modified starch products, many companies often overlook the benefits of cassava itself. Because based on our interviews, companies don't really know the benefits of cassava, said Nana Suryana of Indah Kiat (2017).

\section{- Technology}

From a technological point of view, the machine used to produce modified cassava starch is one of the obstacles in Indonesia. According to Yuliana of PT. BangunCipta Mandiri, we find that we are behind on the top cassava seeds. The cassava harvest in Indonesia is seasonal, making it difficult to be available year round. Hence why the supplier must source from several different sources. The most common come from Central Java, East Java, Lampung and Kalimantan. According to Yuliana of PT BangunCipta Mandiri, even Lampung, as the largest cassava producer, is still struggling to meet demand. Other countries like Thailand and Vietnam lead the cassava market because they have the best seeds. Their research and development on cassava seeds has made the country capable of producing cassava all year round, regardless of the season. The yield also does not damage the nutrients in the soil. Unlike Indonesia, the first reason becomes a problem, as farmers are reluctant to plant cassava for fear of ruining the nutrients in their soil.

\section{- Legal}

It is surprising that the regulations in Indonesia actually impose no burden on investments and imports of modified cassava starch. One of the biggest users of

Modified Cassava Starch In Indonesia, a leading pulp and paper company religiously used modified cassava starch as the main raw material. According to PT Indah Kiat's Nana Suryana, as far back as he can remember, there really hasn't been a problem with the regulations. Indeed, certain conditions have to be met, but it does not become an obstacle / barrier for them to obtain modified cassava starch. The ease of doing business by President Joko Widodo helps boost investment in this area as it is hassle free. Unfortunately, the regulations regarding cassava investment are not very attractive to investors. As a new market, they would hope to become a market leader, but with the investor only keeping $49 \%$ of the stock, most of them are pulling out of the idea. This is reasonable, because the government is not prioritizing cassava promotion, said Septiria Christiani of the Indonesia Investment Coordination Board. While cassava plays a major role in the Thai economy and agriculture, it has since been grown primarily as a cash crop across the country (Win, 2017). 


\section{- Environmental}

Indonesia, while being one of the richest countries in natural resources, is incredibly short of land. Especially on the island of Java where development continues to grow every year, empty land is shrinking. Companies are struggling to find empty land to plant their seeds. The only option is that they may have to plant in other provinces, like Sumatra and Kalimantan. This is not practical, as the factory or head office is mainly located in Java. For suppliers, delivery times and costs are their main concerns. Not to mention a possible problem that could arise during delivery given the Indonesian climate, said Rika Kartika of PT Pulcra Chemicals (2017). Furthermore, the fact that cassava plantation damages soil nutrients has become one of the main reasons why farmers are not interested. They have to work harder to bring the soil nutrients back to their original state. Otherwise, the soil is not good to be planted with anything. According to Septiria Christiani of the Indonesia Investment Coordinating Board (2017), this is why companies must first train farmers before starting any planting and production in Indonesia.

\section{Advantages \& disadvantages}

Here researchers provide the analysis on the advantages and disadvantages of modified cassava starch FDI in Indonesia based on the research results:

Table 3. Modified Cassava Starch FDI Advantages \& Disadvantages (Researchers, 2018)

\begin{tabular}{cc}
\hline ADVANTAGES & DISADVANTAGES \\
\hline Low competition & $\begin{array}{c}\text { Technology limitations on machine and low } \\
\text { quality local seeds }\end{array}$ \\
\hline $\begin{array}{c}\text { Government cutting-off regulations to attract } \\
\text { more investor and leverage the ease of doing } \\
\text { business of Indonesia }\end{array}$ & $\begin{array}{c}\text { Farmers' lack of good cultivation and workshops } \\
\text { on cassava plantation }\end{array}$ \\
\hline $\begin{array}{c}\text { Massive yield of cassava and can easily be } \\
\text { sourced from many regions in Indonesia }\end{array}$ & $\begin{array}{c}\text { Traditional tribe's reluctance to welcome } \\
\text { new technology and growth at some areas in } \\
\text { Indonesia }\end{array}$ \\
\hline $\begin{array}{c}\text { Massive demand in local market yet to be } \\
\text { fulfilled }\end{array}$ & \\
\hline $\begin{array}{c}\text { Economic growth in indonesia increments } \\
\text { beyond 5\% year to year }\end{array}$ & \\
\hline $\begin{array}{c}\text { Modified cassava starch producers' lack } \\
\text { of knowledge on modified cassava starch } \\
\text { applications and benefits }\end{array}$ \\
\hline $\begin{array}{c}\text { Customer of modified cassava starch are not } \\
\text { price sensitive and tendency to substitute } \\
\text { product is low }\end{array}$ \\
\hline
\end{tabular}

\section{Research proposition model}

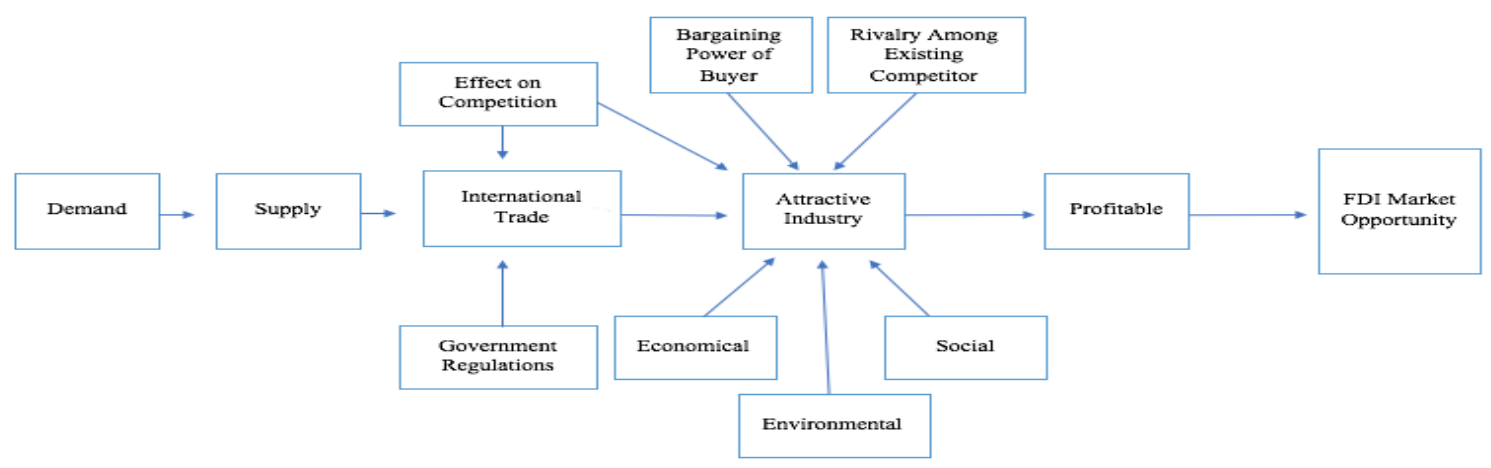

Figure 4. 2 Research Proposition Model (Researchers, 2018) 


\section{Research implications}

\section{- Theoretical}

This research complements the strength of Porter's five forces analysis which asserts that the attractiveness of an industry depends on its profitability. The result of this thesis is an attractive industry with high profitability for foreign direct investment of modified cassava starch in different segments in Indonesia. Daniels, Radebaugh and Sullivan (2015) state in their research that FDI will have access to certain resources in Indonesia, hence end users will turn to these FDI for the supply chain. In general, the researchers found that the desirability of modified cassava starch is moderately impacted by international trade, the effect on competition, and government regulations. The result of this research has proven that it contributes to and further enhances the knowledge of previous research on foreign direct investment.

Research shows that doing business in Indonesia is attractive because FDI keeps increasing, and the result of this research validates research by Gopalan, Hattari and Rajan (2016) which indicates that global inflows of Indonesia's FDI are increasing year by year. Our research shows that in Indonesia the ability to supply and transform cassava into a diversified product for other segments is incompetent with regard to bad technological change, which breaks the statement of Tonukari et al (2015) that assert the contrary. Our research indicates that most aspects of PESTLE affect the decision-making process of FDI and validates the statement by Nganga \& Maruyama (2015), that PESTLE can be used as a tool to assess market attractiveness. Johnson's (2014) research indicates that Porter's five forces analysis can be used to measure the attractiveness of an industry. Our research focuses on the profitability or otherwise of the modified cassava starch market. let us therefore seek to know the attractiveness of the modified cassava starch industry. . Our research supports Johnson's (2014) statement that Porter's five forces analysis can be used to measure the attractiveness of an industry. and help determine whether to enter or avoid the market.

\section{- Managerial}

In general, the result of this research provides information on whether international trade, effect on competition and government regulations are the obstacle. current. In addition to knowing the market opportunities for modified cassava starch. Based on the research carried out, the implications are:

\section{Modified cassava starch is a market full of opportunity according to the research based on Porter's Five Forces.}

As stated by the Ministry of Agriculture (2017), cassava can be processed into so many products, but what kind of product remains to be discovered. First, there is not yet a big competitor in the market. From our research, we found that there are hardly any suppliers of modified cassava starch in Indonesia, not just in Java. Most local suppliers are only able to produce up to 1000 tons / month, which is low compared to demand. Second, local demand is quite high in Indonesia. When we asked our buyer, they wished there were more local suppliers. The local quality is better than the imported one. If only the suppliers were able to meet the demand, they would prefer to choose local suppliers as the delivery time would also be shorter. Third, the delivery time for imports may be a consideration for buyers. Because if a problem occurs with their orders such as damaged goods, late delivery, entry ban or shipment stuck in the port, it will take a long time to order another product to replace it because it is from another. country. That's why local suppliers are easier if something happens with the order. Finally, government regulations are not an obstacle for modified cassava starch. The ease of doing business thanks to President JokoWidodo has helped multinational enterprises (MNEs) interested in investing. There are no complicated regulations, it is mainly there to protect the welfare of local farmers. In fact, for the imports themselves, there are no prohibitions or obstacles that interfere with the imports.

\section{Consumption growth in Indonesia.}

The external factor which makes the investment of modified starch powerful is the growth of the Indonesian economy over the years which, above 5\%, and the Indonesian inflation rate seem to decrease. This fact means that the consumption of products and services in Indonesia will increase dramatically over the next five to ten years, the food and beverage industry sector is still the largest potential market for the use of modified starch. in Indonesia, followed by pulp and paper or what is called the fast moving consumer. good. In addition, the Indonesian political climate does not have a huge impact on foreign direct investment in modified starch. Former Indonesian presidents did not pay attention to the welfare of cassava farmers and the local competitiveness of cassava. 


\section{Local modified cassava starch competitiveness.}

Firstly, the quality of Indonesian cassava is better than that of other countries, because when it comes to the production of modified starch, the less moisture, the better. Cassava in Indonesia tends to be drier and brighter, so when turned into modified cassava starch, the result is a higher quality starch compared to Thailand and Vietnam (Ministry of Agriculture, 2017 ). Second, in terms of modified cassava starch in Indonesia, it is more expensive due to lack of electricity in Indonesia. Companies can easily price their modified cassava starch without following the market price because there is hardly any standard, as long as the price is still acceptable, buyers are still interested. Third, the supply capacity is relatively weak. As mentioned above, there are only several local players in the market, which makes entry easier. If the investor is able to produce modified cassava starch in large quantities, buyers would consider obtaining it from this company. Finally, the delivery time is one of the most important concerns of buyers. Long and expensive delivery can be a problem. Buyers want to have a supplier who can easily meet their demand in the event of a sudden order, deliver to their factory immediately, and reduce lead times for faster production on the buyer's side. At the end of the day, good customer service is what buyers want.

\section{Local modified cassava starch competitiveness.}

Firstly, Indonesia cassava quality is better than other countries because when it comes to modified starch production the less moisture the better. Cassava in Indonesia tends to be in the dryer and brighter side, so when it is processed into modified cassava starch, the result is a better quality starch compared to Thailand and Vietnam (Ministry of Agriculture, 2017). Secondly, In terms of pricing according to Dody from PT. Fajar Surya Wisesa, the modified cassava starch in Indonesia is more expensive due to lack of supply power in Indonesia. Companies can easily price their modified cassava starch without following the market price because there is barely any standard to it, as long as the price is still acceptable the buyers are still interested. Thirdly, the ability to supply is relatively low. As mentioned above, there are only several local players in the market, making it easy to enter. If the investor is able to produce modified cassava starch in a big quantity, buyers would consider on getting it from that company. Lastly, delivery time is one of the most important concerns for buyers. Lengthy and costly delivery can be a concern. Buyers want to have a supplier that can easily provide their demand if a sudden order were to occur, can deliver immediately to their factory, and cut delivery time for faster production on the buyers' side. Ultimately, a good customer service is what the buyers wish for.

\section{CONCLUSIONS}

We provide a brief conclusion on our research findings based on our analysis to the foreign investor whether to enter the market or avoid it. We also provide recommendations to the government and the local manufacturer of modified cassava.

In terms of international trade, effect on competition and government regulation, competition in the modified cassava starch industry affects the attractiveness of the industry itself with regard to the power of high buyer's negotiation. Thus, the effect on competition is currently not a barrier to entry into the market. The common obstacle for international trade to enter the market is the massive number of modified cassava starch imported from Vietnam, Thailand and other countries. The Indonesian government is currently supporting foreign investors to develop the economy, so government regulation is not an obstacle.

The modified cassava starch market in Indonesia is full of potential and opportunity, with high profitability due to lack of competition in the market. The market is in high demand and will continue to grow as more industries use modified cassava starch as a raw material. The idea of having a company capable of producing in large quantities in the face of strong market demand.

Our recommendations to companies that will invest and enter the Indonesian market are as follows:

- Focus on product quality, especially for industries other than food and beverage, where brightness and other contents are of great concern

- Bringing new technologies to widen the variety of product applications and produce large quantities to meet customer expectations 
- Effortless delivery system and experience for customers, especially for damaged goods, exchanges, returns or refunds.

- Good and quick response for customer service is crucial as it is a main force where the company can compete on imported modified cassava starch.

Based on the research and findings, our recommendation for further research:

- Further research on the feasibility of modified cassava starch for investment in the project. Provide FDI companies with a clearer picture of the Indonesian modified cassava starch market.

- Overview of modified cassava starch capacity and production, especially in Indonesia. Improve the FDI company's ability to maximize production to meet demand.

- Modified cassava starch supply chain, price and gross margin analysis to improve business and operational efficiency.

- Further investigation of major customers of Modified Cassava Starch in Indonesia, to find out untapped industries and their customized specifications.

\section{REFERENCES}

Adhana, D. K. (2016). Foreign Direct Investment in Indian Agricultural Sector : Opportunities and Challenges. $3(2), 34-46$.

Anton, R. (2015). An Integrated Strategy Framework (ISF) for Combining Porter's 5-Forces, Diamond, PESTEL, and SWOT Analysis. Munich Personal RePEc Archive, 4(1), 24.

Budiman, B. 2 October (2016). Petani Lampung JanganLagiJualSingkongMentah. (Online). Retrieved on June 14, 2017 from https://lampung.antaranews.com/berita/292475/petani-lampung-jangan-lagi-jual-singkong-mentah

Chartered Management Institute. November (2013). Carrying Our A PEST Analysis Checklist. (Online). Retrieved on October 23, 2017 from http://www.managers.org.uk/ /media/Files/Campus\%20CMI/Checklists\%20PDP/Carrying\%20out\%20a\%20PEST\%20analysis

Cheng, D. (2013). Analyze the Hotel Industry in Porter Five Competitive Forces. The Journal of Global Business Management, 9(3), 52-57.

Claire. 22 February (2017). Modified Starch Market by Raw Material, Function, Application, and Region - Global Forecast to 2022. (Online). Retrieved on July 9, 2017 from https://www.prnewswire.com/news-releases/modified-starch-market-by-raw-material-function-application-and-region---global-forecastto-2022-300412218.html.

Creswell, J. W. (2014). Research Design: Qualitative, Quantitative, and Mixed Methods Approaches. United States: SAGE Publication, Inc.

Dalken, F. (2014). Are Porter's Five Competitive Forces still Applicable? A Critical Examination concerning the Relevance for Today's Business. IBA Bachelor Thesis Conference, 2-3.

Daniels J. D., Radebaugh R. H., \& Sullivan D. P. (2015). International Business, Global Edition: Environments and Operations. United States: Courier Kendalville.

Deny, S. 25 January (2017). Jokowi: PertumbuhanEkonomi Indonesia Termasuk yang Terbaik. (Online). Retrieved on September 25, 2017 from http://bisnis.liputan6.com/read/2836969/jokowi-pertumbuhan-ekonomi-indonesia-termasuk-yang-terbaik

Deri, E. (2015).Challenges of Environmental and Social Responsibility in the Fashion Industry.

Dhanya\&Ramachandran. (2014). A Study About Foreign Direct Investment in Indonesia. IOSR Journal of Business and Management, 16(2), 47. 
Dockalikova I. \&Kashi K. (2014). MCDM Methods in Practice: Determining Importance of PESTEL Analysis Criteria. The 8th International Days of Statistics and Economics.

Elboiashi, H. (2015). The effect of FDI on economic growth and the importance of host country characteristics. Journal of Economics and International Finance, 7(2), 25-41.

Eskandari, M. J., Miri, M., Glolami, S., Nia, H. R. S. (2015). Factor That Affecting Competitiveness of The Food Industry By Using Porter's Five Forces Model Case Study In Hamadan Province, Iran. Journal of Asian Scientific Research, 5(4), 191.

Fitriandi P., Kakinaka M., \&Kotani K. (2014). Foreign direct investment and infrastructure development in Indonesia: Evidence from province level data. Asian Journal of Empirical Research, 4(1), 79-94.

Francisca C. \&Lantu D. C. (2014). Developing Bandung Store In Singapore: A Preliminary Study. Journal of Business Management, 3(4), 412.

Giuseppina, T. (2016). Foreign Direct Investment Flows and Global Economic Crisis. Special Conference issue" Past and Future of Corporate Governance: Practices, Reforms and Regulations”, 13(4), 266-267.

Gopalan. S, Hattari R., \&Rajan, R. S. (2016). Understanding foreign direct investment in Indonesia. Journal of International Trade Law and Policy, 15(1), 29-31.

Grand View Research. April (2016). Modified Starch Market Size Worth \$15.36 Billion By 2024. (Online). Retrieved on July 9, 2017 from https://www.grandviewresearch.com/press-release/global-modified-starch-market

Gupta, A. (2013). Environment \& PEST Analysis: An Approach to External Business Environment. International Journal of Modern Social Sciences, 2(1), 35-43.

Harrell, L. (2016). British Protelum (BP): Critical Analysis on Its Corporate And International Strategies. International Journal of Research in IT \& Management, 6(3), 138.

Ho, J. K. (2014). Formulation of a Systemic PEST Analysis for Strategic Analysis.European Academic Research, 2(5), 6478-6492.

HumasKementrianKoordinatorBidangPerekonomian. 21 October (2015). 1 TahunPemerintahanJokowi-JK: PaketKebijakanEkonomi, BangkitkanKepercayaanPasar. (Online). Retrieved on September 25, 2017 from https://www.ekon.go.id/

Indiatsy C., Mwangi M., Mandere E., Bichanga J., \& George G. (2014). The Application of Porter's Five Forces Model on Organization Performance: A Case of Cooperative Bank of Kenya Ltd. European Journal of Business and Management, 6(16), 75-85.

Johnson, M. L. S. L. F. (2014). The 5 Competitive Forces Framework in a technology mediated environment. Do these forces still hold in the industry of the 21st century?.IBA Bachelor Thesis Conference, 2-3.

Jovovic D., Jovanovic S., \&Dasic B. (2014). Agricultural Trade and Financing Through FDI. Economic of Agriculture, 61(2), 466-467.

Kastrati, S. K. (2013). Demand and Determinants of FDI: A Knowledge Capital Approach. European Journal of Interdiscplinary Studies, 5(1), 37.

Koumparoulis, D. N. (2013). PEST Analysis: The Case of E-shop. International Journal of Economy, Management and Social Science, 2(2), 31-36.

Litavniece L. \&Znotina D. (2015). External Business Environment Problems and Opportunities in Rezekne City. Journal of Social Sciences, 1(7), 107-119.

Mel, B. B., Katuse, P., Namanda, J. (2016). Influence of Threat New Entrants on Performance of Oil Industry In South Sudan.International Journal of Novel Research in Marketing Management and Economics, 3(2), 158.

Ministry of Agriculture, Pusat Data danSistemInformasiPertanian. (2016). Outlook UbiKayu 2016. Jakarta: KementrianPertanian.Narula R. \&Pineli A. (2016). Multinational Enterprises and Economic Development in Host Countries: What We Know and What We Don't Know.

Nganga S. P. \& Maruyama Y. (2015). Market Attractiveness Evaluation of Sub Sahara Africa, Applying SWOT Analysis and AHP.Journal of Economics and Economic Education Research, 16(1), 1. 
Njambi E., Lewa P., \&Katuse P. (2016). Relationship between Threat of Substitutes and Competitive Advantage of Large Multinationals in Kenyan Beverage Industry.The International Journal Of Business \& Management, 4(7), 412-423.

Ozer K. \&Saldamli A. (2015).Evaluation of Competition Conditions in the Hotel Sector in Istanbul.International Review of Management \& Marketing, 5(2), 102-107.

Rahmadyanti E. \&Dwijanto A. (2016). Implementing Cleaner Production as An Environmental Management Efforts in Small Industries of Cassava Chips. MATEC Web of Conferences.

Rahman, T. 13 March (2015). TepungMocaf: ProdusenTepungSingkongKaltimKewalahan. (Online). Retrieved on September 25, 2017 from http://industri.bisnis.com/read/20150313/99/411593/tepung-mocaf-produsen-tepung-singkong-kaltim-kewalahan.

Rastogi N. \&Trivedi M. K. (2016). PESTLE Techinque - A Tool to Identify External Risks in Construction Projects. International Research Journal of Engineering and Technology, 3(1), 384-388.

Saediman H., Amini A., Basiru R., \&Nafiu L. O. (2015). Profitability and Value Addition in Cassava Processing in Buton District of Southeast Sulawesi Province, Indonesia.Journal of Sustainable Development, 8(1), 226-234.

Sekaran U. \&Bougie R. (2014). Research Methods for Business: A Skill-building Approach. Italy: Printer Trento Srl.

Singh A. V., Singh A., \&Nath L. (2017). Pharmaceutical, food and non-food applications of modified starches: A critical review. Electronic Journal of Environmental, Agricultural, and Food Chemistry, 9(7), 12141221.

Sjoholm, F. (2016). Foreign Direct Investment and Value Added in Indonesia. The Research Institute of Industrial Economics.

Srdjevic Z., Bajcetic R., \&Srdjevic B. (2012). Identifying the Criteria Set for Multicriteria Decision Making Based on SWOT/PESTLE Analysis: A Case Study of Reconstructing A Water Intake Structure. Water Resources Management: An International Journal, Published for the European Water Resources Association (EWRA), 26(12), 3379-3393.

Talib M., Hamid A., Zulfakar M., \&Jeeva A. (2014). Halal Logistics PEST Analysis: The Malaysia Perspectives. Asian Social Science, 10(14), 119-131.

Tambunan, T. H. (2014). Identifying Business Models Adopted by FDI in Agriculture in Indonesia. Journal of Economics and Development Studies, 2(1), 126-127.

Tonukari N., Ezedom T., Enuma C., Sakpa S., Avwioroko O., Eraga L., \&Odiyoma E. (2015). White Gold: Cassava as An Industrial Base. Journal of Plant Sciences, 6, 1-3.

UNICEF. January (2017). SWOT and PESTEL: Understanding Your External and Internal Context for Planning and Decision-making. (Online). Retrieved on October 8, 2017 from https://www.unicef.org/knowledge-exchange/files/SWOT_and_PESTEL_production.pdf

Vieira J., Cram B., Jang K., Grady H., \& Fairburn B. (2015). Considerations in IKEA Product Design.Business Management in The Wood Industry.

Wanandi, S. 18 March (2013). MengapaPengusahaSukaImporPadahal RI PunyaPabriknya. (Online). Retrieved on June 14, 2017 from http://bisnis.liputan6.com/read/538319/mengapa-pengusaha-suka-impor-padahal-ri-punya-pabriknya

Widiastuti, D., Herlina, E., Mulyati, A. H., Warnasih, S. (2016). Diversification of Cassava Flour in the Manufacture of Gluten-Free Flakes Enriched with Dietary Fibers from Virgin Coconut Oil Waste Flour.Journal of Agricultural Science and Technology.

Win H. E. (2017). Role of Cassava in Thailand.Center for Applied Economic Research.

Yuksel, I. (2012) Developing a Multi-Criteria Decision Making Model for PESTEL Analysis.International Journal of Business and Management, 7(24), 52-66. 